\title{
EVALUASI KINERJA KOMITE SEKOLAH DALAM PENINGKATAN MUTU PENDIDIKAN
}

\author{
Bambang Suteng Sulasmono ${ }^{1}$ dan Murjini ${ }^{2}$ \\ ${ }^{1}$ FKIP Universitas Kristen Satya Wacana, ${ }^{2}$ SD Sukomarto \\ email: sulasmonobambang@yahoo.com
}

\begin{abstract}
Abstrak: Penelitian evaluatif ini bertujuan untuk mengevaluasi kinerja Komite Sekolah sebagai badan pemberi pertimbangan, badan pendukung, badan pengontrol sebagai badan penghubung di SD Negeri Sukomarto Jumo Temanggung. Subjek penelitian adalah Komite Sekolah, Kepala Sekolah, dan Guru SD Negeri Sukomarto. Pengumpulan data dengan teknik wawancara, pengamatan, dan studi dokumentasi. Analisis data dilakukan dengan teknik analisis data kualitatif. Hasil penelitian menunjukkan bahwa kinerja Komite Sekolah sebagai badan pemberi pertimbangan, badan pendukung, badan pengontrol, dan badan penghubung di SD Negeri Sukomarto, sudah dilaksanakan sesuai dengan yang acuan resmi yang berlaku. Tetapi, kinerja Komite Sekolah sebagai penghubung antara Komite Sekolah dengan Dewan Pendidikan belum bisa dilaksanakan secara maksimal. Selain itu, kegiatan yang sudah dilaksanakan tidak didokumentasikan sehingga terkesan tidak tertib adminstrasi.
\end{abstract}

Kata kunci: evaluasi kinerja, Komite Sekolah, mutu pendidikan

\section{EVALUATION ON THE PERFORMANCE OF SCHOOL COMMITTEE IN IMPROVING EDUCATION QUALITY}

\begin{abstract}
This evaluative research aims to evaluate the commitees' performance as an advisory agency, supporting agency, controlling agency and mediator agency at Sukomarto Elementary School, Jumo, Temanggung. The research subjects were school committee, principal, and teachers of Sukomarto Elementary School. Methods of data collection were interview, observation, and documentation. Data were analysed using qualitative technique. The results show that school committeeve performed as advisory agency, supporting agency, controlling agency, and mediator agency at Sukomarto Elementary School according to the regulation. However, their function as liaison between the School Committee with the Board of Education has not been fully implemented. Besides, activities were not well documented.
\end{abstract}

Keyword: performance evaluation, school committee, education quality

\section{PENDAHULUAN}

Manajemen Berbasis Sekolah (MBS) adalah pengelolaan pendidikan yang memberikan otonomi yang seluas-luasnya pada sekolah untuk pengambilan keputusan yang melibatkan secara langsung semua warga sekolah, termasuk partisipasi masyarakat untuk meningkatkan mutu pendidikan serta keunggulan masyarakat dan bangsa (Mulyasa, 2009:24, Nurkolis, 2003:1, Permadi, 2010:26, dan Fattah, 2000:17). Dengan diterapkannya MBS tersebut, sekolah dapat mengoptimalkan sumberdaya yang tersedia untuk memajukan sekolah, karena bisa lebih mengetahui peta kekuatan, kelemahan, peluang dan ancaman yang mungkin dihadapi. Di samping itu, sekolah lebih mengetahui kebutuhannya, khususnya input dan output pendidikan yang akan dikembangkan dan didayagunakan dalam proses pendidikan sesuai dengan perkembangan dan kebutuhan peserta didik.

Dalam pelaksanaan MBS partisipasi masyarakat merupakan satu keniscayaan. Partisipasi masyarakat mempunyai peranan strategis dalam rangka usaha mengadakan pembinaan, pertumbuhan, dan pengembangan siswa di sekolah. Dengan adanya hubungan kerja sama antara sekolah dengan masyarakat, dapat dicapai perpaduan antara sarana-prasarana yang dimiliki sekolah dengan yang dimiliki masyarakat. Hubungan yang harmonis antara keduanya dalam pengembangan program bersama bagi pembinaan peserta didik, dapat mengurangi dan mencegah kemungkinan anak berbuat yang tidak baik, karena program yang padat dan menarik tidak memberi kesem- 
patan kepada peserta didik untuk melakukan perbuatan yang tidak baik (Mulyasa, 2009:50, 2009:163, Undang-Undang RI Nomor 20 Tahun 2003). Pengembangan pendidikan sekarang ini lebih diarahkan kepada upaya peningkatan partisipasi masyarakat, sehinggga sekolah yang berada di tengah-tengah masyarakat itu benar-benar menjadi milik dan tanggung-jawab masyarakat. Dengan demikian, kerja sama antara sekolah dan masyarakat perlu dikembangkan.

Komite Sekolah adalah suatu lembaga yang berkedudukan di setiap satuan pendidikan, serta merupakan badan mandiri yang tidak memiliki hubungan hierarki dengan lembaga pemerintahan yang berada di tengah-tengah antara orang tua murid, murid, guru, masyarakat setempat, dan kalangan swasta yang dibentuk dan berperan dalam peningkatan mutu pelayanan dengan memberikan pertimbangan, arahan dan dukungan tenaga, sarana prasarana, serta pengawasan pendidikan pada tingkat satuan pendidikan (Masaong dan Ansar, 2007:165; Hasbullah, 2006:90, dan UU Nomor 20 Tahun 2003). Kepengurusan dan keanggotaan dalam Komite Sekolah harus mencerminkan orang tua peserta didik dan tokoh-tokoh masyarakat. Kepengurusan dan keanggotaan Komite Sekolah meliputi: (1) perwakilan orangtua siswa, (2) tokoh masyarakat seperti kepala dusun, ulama, budayawan, dan sebagainya, (3) anggota masyarakat seperti LSM peduli pendidikan, (4) pejabat pemerintah setempat, (5) dunia usaha dan dunia industri (DUDI), (6) pakar pendidikan, (7) organisasi profesi tenaga kependidikan seperti PGRI, (8) perwakilan siswa, dan atau alumni (Haryanto, 2008:96).

Tujuan Komite Sekolah adalah untuk: (1) mewadahi dan menyalurkan aspirasi dan prakarsa masyarakat dalam melahirkan kebijakan operasional dan program pendidikan di satuan pendidikan; (2) meningkatkan tanggung jawab dan peran serta masyarakat dalam menyelenggarakan pendidikan di satuan pendidikan; (3) menciptakan suasana dan kondisi transparan, akuntabel, dan demokratis dalam penyelenggaraan dan pelayanan pendidikan yang bermutu di satuan pendidikan (Haryanto, 2008:81). Sementara itu, Keputusan Menteri Pendidikan Nasional Nomor 044/U/2002 tentang Dewan Pendidikan dan Komite Sekolah menyebutkan bahwa Komite Sekolah mengemban peran sebagai: (1) pemberi pertimbangan (advisory agency); (2) pendukung (supporting agency); (3) pengawas (controlling agency); dan
(4) penghubung (Mediator Agency).

Sejumlah penelitian terdahulu tentang Komite Sekolah menunjukkan hasil yang beragam. Ada sejumlah peneliti yang menemukan bahwa Komite Sekolah sudah berperan dengan baik, tetapi sejumlah peneliti lain menemukan bahwa Komite Sekolah belum bisa berperan dengan baik. Studi yang dilakukan oleh Armansyah (2009) yang berjudul "Peranan dan Pemberdayaan Komite Sekolah dalam Penyelengaraan Pendidikan SMA Negeri di Kota Binjai" misalnya, menyimpulkan bahwa Komite Sekolah belum mampu melaksanakan peranannya baik sebagai badan pemberi pertimbangan, badan penghubung, badan pengontrol maupun sebagai badan pendukung. Sementarn penelitian Ninik (2011) yang berjudul "Peranan Komite Sekolah Dalam Pembiayaan Pendidikan di SMA Negeri 1 Tuntang Kabupaten Semarang" menyimpulkan bahwa Komite Sekolah SMA Negeri I Tuntang telah menjalankan fungsinya sebagai badan pertimbangan (Advisory Agency) dalam penyusunan biaya pendidikan yang tertuang dalam RAPBS. Nyandoro (2013) melalui penelitianya yang berjudul "Effectiveness Of School Development Committees In Financial Management In Chimanimani West Circuit Primary Schools In Zimbabwe" menyimpulkan bahwa Pengembangan Komite Sekolah tidak efektif dalam mengelola dana untuk sekolah mereka karena kurangnya keterampilan dalam berbagai aspek manajemen keuangan seperti persiapan dan penggunaan anggaran untuk membuat keputusan, menjaga aset inventarisasi sekolah dan penggalangan dana.

Berdasarkan latar belakang di atas, perlu juga diketahui bagaimana kinerja Komite Sekolah di SD Negeri Sukomarto. Apabila kinerja Komite Sekolah di SD Negeri Sukomarto belum sesuai dengan yang diamanatkan dalam Keputusan Mentri Pendidikan Nasional Nomor 044/U/2002 Tentang Dewan Pendidikan dan Komite Sekolah berarti kinerjanya belum baik, tetapi apabila sudah sesuai berati sudah baik dan apabila lebih dari yang diamanatkan dalam Keputusan Menteri Pendidikan Nasional Nomor 044/U/2002 Tentang Dewan Pendidikan dan Komite Sekolah berarti kinerjanya baik sekali.

Sebelum tahun pelajaran 2010/2011 SD Negeri Sukomarto merupakan sebuah sekolah yang sangat memprihatinkan, jumlah siswanya hanya 60 siswa, sarana prasarananya sangat kurang dan jarang mendapatkan kejuaraan. Na- 
mun sejak tahun pelajaran 2010/2011 sampai tahun pelajaran 2014/2015 SD Negeri Sukomarto mengalami banyak peningkatan, baik di bidang mutu pendidikan (bidang akademik maupun non akademik), sarana prasarana, maupun jumlah siswanya. Keberhasilan ini diduga terwujud karena adanya hubungan yang harmonis antara Sekolah dengan Komite Sekolah. Fenomena ini menarik untuk dikaji lebih mendalam melalui sebuah penelitian tentang kinerja Komite Sekolah baik sebagai badan pemberi pertimbangan ( $a d-$ visory agency), pendukung (supporting agency), pengontrol (controlling agency), maupun sebagai badan penghubung (mediator agency)

Sejalan dengan latar belakang di atas maka rumusan masalah dari penelitian ini adalah bagaimana kinerja Komite Sekolah sebagai badan pemberi pertimbangan (advisory agency), sebagai badan pendukung (supporting agency), sebagai badan pengontrol (controlling agency) dan sebagai badan penghubung (Mediator Agency) di SD Negeri Sukomarto. Sesuai dengan rumusan masalah di atas, maka tujuan dari penelitian ini adalah kinerja Komite Sekolah sebagai badan pemberi pertimbangan (advisory agency), sebagai badan pendukung (supporting agency), sebagai badan pengontrol (controlling agency) dan sebagai badan penghubung (Mediator Agency) di SD Negeri Sukomarto Kecamatan Jumo, Kabupaten Temanggung

Secara teoritis penelitian ini diharapkan bermanfaat untuk mengembangkan ilmu manajemen pendidikan, terutama mengenai kinerja Komite Sekolah. Sedang secara praktis hasil penelitian ini diharapkan dapat dimanfaatkan oleh Komite Sekolah yang bersangkutan untuk mengembangkan kinerjanya. Bagi sekolah hasil penelitian ini diharapkan dapat menjadi masukan dalam merumuskan rencana kegiatan pengembangan sekolah terkait dengan peningkatan mutu pendidikan, serta meningkatkan kerjasama dengan Komite Sekolah.

\section{METODE}

Penelitian ini adalah penelitian evaluatif karena hendak mengevaluasi kinerja Komite Sekolah dalam peningkatan mutu pendidikan di SD Negeri Sukomarto sebagaimana diamanatkan oleh Keputusan Menteri Pendidikan Nasional Nomor 044/U/2002 tentang Dewan Pendidikan dan Komite Sekolah. Penelitian ini dilakukan di SD Negeri Sukomarto yang beralamat di Desa Suko- marto Kecamatan Jumo Kabupaten Temanggung, dengan subjek penelitian Komite Sekolah, Kepala Sekolah dan Guru-guru SD Negeri Sukomarto. Penelitian ini dilakukan mulai Bulan Februari 2015 sampai Mei 2015. Evaluasi Kinerja Komite Sekolah memiliki dua kegiatan utama, yaitu pengukuran atau pengumpulan data, dan membandingkan hasil pengukuran dan pengumpulan data dengan standar yang sudah ditentukan (Instrumen Indikator Kinerja Komite Sekolah).

Secara lebih lengkap penelitian menggunakan langkah penelitian evaluatif dari Simanjuntak (2005:141) yaitu: (1) menghimpun semua informasi; (2) mendiskripsikan unsur kinerja dari setiap informasi yang dihimpun; (3) membuat kajian atas kinerja, serta membandingkanya dengan tolok ukur atau sasaran yang harus dicapai (trandar yang sudah ditetapkan); (4) menarik kesimpulan dari pelaksanaan penilaian; dan (5) merumuskan saran-saran tindak lanjut. Teknik pengumpulan data yang digunakan dalam penelitian ini adalah wawancara, pengamatan dan studi dokumen. Validasi data dilakukan melalui triangulasi, teknik dan triangulasi sumber. Teknik analisis data dalam penelitian ini adalah teknik analisis data kualitatif yang dilakukan sejak sebelum memasuki lapangan yaitu data sekunder, selama di lapangan,dan setelah selesai di lapangan.

\section{HASIL DAN PEMBAHASAN \\ Hasil \\ Kinerja Komite Sekolah Sebagai Badan Pem- beri Pertimbangan}

Dari hasil wawancara dengan beberapa informan dan studi dokumen tampak bahwa kinerja Komite Sekolah di SD Negeri Sukomarto dalam perencanaan sekolah, sudah berjalan sesuai dengan peran dan fungsinya. Sekolah selalu mengundang Komite Sekolah dalam penyusunan RAPBS. Dalam rapat tersebut Komite sekolah memberikan masukan, pertimbangan dan juga ikut mengesahkan RAPBS. Dalam pelaksanaan program sekolah, Komite Sekolah sering memberikan masukan terhadap proses pengelolaan pendidikan, dan juga memberikan masukan-masukan terhadap proses pengelolaan dan pembelajaran di sekolah. Salah satu contoh adalah masukan agar sekolah mengadakan program tambahan jam pelajaran yang sampai sekarang masih berjalan. Dengan adanya program ini sedikit demi sedikit prestasi SD Negeri Sukomarto semakin meningkat baik dibidang akademik maupun nonakademik. 
Dalam hal pengelolaan sumberdaya pendididkan baik sumberdaya manusia, sarana dan prasarana maupun anggaran, Komite Sekolah aktif memberikan pertimbangan. Anggota Komite Sekolah mayoritas warga asli penduduk sekitar sekolah, bahkan ketua Komite Sekolah SD Negeri Sukomarto adalah perangkat desa tersebut, sehingga dapat dengan mudah mengidentifikasi potensi sumberdaya masyarakat yang dapat dimanfaatkan bagi kemajuan sekolah. Dalam pengelolaan sarana dan prasarana serta anggaran sekolah, Komite Sekolah selalu memberikan pertimbangan baik yang bersifat teknis maupun anggaran. Hal ini dibuktikan dengan adanya pembahasan bersama antara sekolah dengan Komite Sekolah dalam rencana pengadaan laptop, wastafel, pembangunan mushola sekolah dan lainlain. Uraian diatas menunjukkan bahwa kinerja Komite Sekolah SD Negeri Sukomarto sebagai badan pemberi pertimbangan dalam menjalankan fungsi perencanaan sekolah, pelaksanaan program, dan pengelolaan sumberdaya pendidikan telah berjalan dengan baik.

\section{Kinerja Komite Sekolah Sebagai Badan Pen- dukung}

Kinerja Komite Sekolah sebagai badan pendukung (supporting agency) di SD Negeri Sukomarto, dalam hal pengelolaan sumber daya sekolah dilakukan dengan memantau kondisi ketenagaan pendidikan di sekolah, mobilisasi guru sukarelawan untuk menangggulangi kekurangan guru di sekolah, serta mobilisasi tenaga kependidikan non guru untuk mengisi kekurangan di sekolah. Dari hasil pengamatan dan studi dokumen ditemukan bahwa terdapat 4 (empat) tenaga honorer yang terdiri dari 3 (tiga) orang guru dan seorang penjaga sekolah di SD Negeri Sukomarto yang pengangkatannya juga melalui pelibatan Komite Sekolah. Hal ini menunjukkan bahwa Komite Sekolah sudah berperan aktif dalam menangggulangi kekurangan guru di sekolah, serta memobilisasi tenaga kependidikan nonguru untuk mengisi kekurangan di sekolah.

Selain itu, Komite Sekolah SD Negeri Sukomarto juga mengkoordinir bantuan sarana dan prasarana dari masyarakat kepada sekolah serta mengevaluasi pelaksanaanya. Hal ini dibuktikan dengan adanya usaha memobilisasi dan mengkoordinasi dukungan dan bantuan pembangunan mushola sekolah, yang pada saat itu sangat dibutuhkan baik oleh siswa sendiri maupun oleh semua guru. Bahkan Komite Sekolah dan perangkat desa sendiri yang menggalang dana dari masyarakat melalui pertemuan-pertemuan di desa, sehingga terkumpul dana yang mencukupi bagi pembangunan mushola sekolah.

Dukungan yang diberikan oleh Komite Sekolah tidak hanya sebatas dukungan dana saja, tetapi juga dukungan tenaga dan pikiran. Seperti pada waktu sekolah belum punya laptop, padahal semua laporan dianjurkan untuk diketik, maka Komite Sekolah mengusahakanya dengan cara melelang bahan bongkaran bangunan sisa program DAK bantuan berupa ruang kelas baru. Dana hasil lelang itu kemudian digunakan untuk membeli laptop dan printer. Komite Sekolah juga menjalin hubungan dengan dunia usaha dan dunia industri, sewaktu sekolah membutuhkan wastafel untuk menanamkan budaya cuci tangan kepada para siswa. Komite Sekolah mengusahakan pengadaan wastafel tersebut melalui program PAMSIMAS (Penyediaan Air Minum dan Sanitasi berbasis Masyarakat). Hasilnya dapat diamati yang tersedianya wastafel di setiap ruang kelas SD Negeri Sukomarto. Dengan semakin lengkapnya sarana dan prasarana yang dimiliki, hal itu akan mendukung kelancaran proses belajar mengajar di sekolah, sehingga akan berdampak pada peningkatan mutu pendidikan.

Kinerja Komite Sekolah sebagai badan pendukung dalam pengelolaan anggaran dilakukan dengan memantau kondisi anggaran sekolah dalam laporan yang diberikan oleh Kepala Sekolah. Mobilisasi dukungan anggaran sekolah dilakukan oleh Komite Sekolah dengan mendorong perhatian dan bantuan dana dari masyarakat. Komite Sekolah juga mengevaluasi pelaksanaan dukungan anggaran dua kali dalam setahun, yaitu di tengah tahun dan akhir tahun. Evaluasi di tengah tahun dilakukan dengan tujuan untuk mengetahui jumlah anggaran yang telah masuk dan yang telah digunakan, serta kendalanya. Sedangkan di akhir tahun bertujuan untuk mengetahui sejauh mana tingkat ketercapaian program sesokal dan untuk merencanakan RAPBS tahun berikutnya.

Dari hasil wawancara, dokumentasi dan pengamatan, dapat disimpulkan bahwa kinerja Komite Sekolah sebagai badan pendukung (supporting agency) di SD Negeri Sukomarto sudah dilaksanakan sesuai peran dan fingsinya yaitu dengan mengelola sumberdaya, sarana dan prasarana, serta mengelola anggaran. 


\section{Kinerja Komite Sekolah Sebagai Badan Pengontrol}

Peran Komite Sekolah sebagai badan pengontrol (controlling agency) dilakukan dengan mengontrol perencanaan pendidikan di sekolah yang meliputi proses pengambilan keputusan, kualitas kebijakan, proses perencanaan pendidikan, pengawasan terhadap kualitas perencanaan sekolah, dan pengawasan terhadap kualitas program sekolah. Komite Sekolah mengontrol perencanaan pendidikan tersebut bersamaan dengan rapat sekolah, misalnya saat rapat penentuan RAPBS di sekolah, rapat pleno dan sebagainya. Di samping itu Komite Sekolah juga mencermati laporan kepala sekolah tentang perencanaan pendidikan tersebut. Jadi tidak ada jadwal khusus bagi Komite Sekolah untuk melakukan fungsi kontrol, sehingga pelaksanaannya tidak secara periodik (terencana). Hal ini disebabkan karena para anggota Komite Sekolah mempunyai kesibukan sendiri sesuai dengan profesi masing-masing, di samping karena memang di SD Negeri Sukomarto tidak ada anggaran untuk biaya operasional Komite Sekolah.

Kinerja Komite Sekolah SD Negeri Sukomarto dalam hal memantau pelaksanaan program sekolah, yang terdiri dari memantau organisasi sekolah, memantau penjadwalan program sekolah, memantau alokasi anggaran untuk pelaksanaan program sekolah, memantau sumber daya pelaksana program sekolah, memantau partisipasi stakeholder pendidikan dalam pelaksanaan program sekolah, juga dilaksanakan melalui laporan yang disampaikan oleh Kepala Sekolah. Dalam hal ini Komite Sekolah memberikan masukan atau saran-saran tentang proses belajar mengajar kepada sekolah, misalnya menyarankan untuk selalu memberi tugas rumah kepada siswa agar para siswa tetap belajar di rumah setiap harinya.

Pemantauan terhadap output pendidikan merupakan bagian dari kinerja Komite Sekolah dalam menjalankan peran dan fungsinya sebagai badan pengontrol. Sebagaimana yang dilakukan oleh Komite Sekolah dalam memantau hasil ujian akhir sekolah, angka partisipasi sekolah, memantau angka mengulang sekolah dan memantau angka bertahan di sekolah dilakukan secara berkelanjutan. Komite melakukan pemantauan melalui laporan yang disampaikan oleh Kepala Sekolah. Komite Sekolah selalu memperhatikan hasil ujian akhir sekolah. Apabila hasilnya kurang baik Komite selalu mencari penyebabnya dan berusaha mencari solusinya. Untuk meningkatkan mutu lulusan Komite Sekolah juga mengusulkan agar sebelum ujian dilaksanakan, diselenggarakan mujahadah bersama antara wali murid, siswa, dan juga Komite Sekolah, serta guru di mushola sekolah.

Komite Sekolah juga sangat memperhatikan angka partisipasi sekolah, mereka selalu menganjurkan kepada wali murid kelas enam untuk menyekolahkan anaknya ke jenjang lebih lanjut, sehingga sewaktu ada anak yang tidak melanjutkan ke SMP/MTs Komite Sekolah datang ke sekolah untuk melaporkanya, sehingga kepala sekolah dan guru kelas enam datang ke rumah siswa tersebut untuk menanyakan apa penyebabnya. Ternyata penyebabnya karena tidak ada biaya dan setelah diberikan solusinya, siswa tersebut bisa melanjutkan ke SMP.

Dari uraian diatas menunjukkan bahwa kinerja Komite Sekolah SD Negeri Sukomarto dalam menjalankan peran dan fungsinya sebagai badan pengontrol (controlling agency) sudah dilaksanakan dengan baik, walaupun belum maksimal karena dilaksanakan bersamaan dengan dengan rapat dan melalui laporan dari pihak sekolah.

\section{Kinerja Komite Sekolah Sebagai Badan Peng- hubung}

Peran Komite Sekolah sebagai badan penghubung (Mediator Agency) dilakukan melalui keterlibatan Komite dalam manajemen pendidikan (perencanaan, pelaksanaan program, dan pengelolaan sumberdaya pendidikan). Dalam perencanaan Komite Sekolah idealnya menjadi penghubung antara Komite Sekolah dengan masyarakat, Komite Sekolah dengan sekolah dan Komite Sekolah dengan Dewan Pendidikan. Sebagai penghubung Komite Sekolah SD Negeri Sukomarto menjalin hubungan yang baik dengan semua pihak, sehingga memudahkan dalam kegiatan dan pemecahan permasalahan sekolah. Tetapi sayangnya sampai saat ini Komite Sekolah SD Negeri Sukomarto belum dapat menjalin hubungan dengan Dewan Pendidikan. Terkait dengan aspirasi dan usulan kebijakan program pendidikan kepada sekolah, Komite Sekolah secara terbuka menerima segala aspirasi masyarakat demi peningkatan kualitas sekolah serta kebutuhan masyarakat.

Kinerja Komite Sekolah terkait dengan peran dan fungsi komite dalam pelaksanaan pro- 
gram, turut serta dalam mensosialisasikan kebijakan dan program sekolah kepada masyarakat, memfasilitasi berbagai masukan, menampung pengaduan terhadap kebijakan sekolah, serta mengkomunikasikan pengaduan dan keluhan masyarkat kepada sekolah. Jadi setiap keputusan yang dihasilkan dalam rapat tersebut adalah aspirasi atau keinginan yang muncul dari masyarakat. Kemudian hasil rapat tersebut disampaikan kepada sekolah untuk ditindak lanjuti dan seterusnya akan dilaksanakan. Dalam pelaksanaan program, apa yang dihasilkan dalam musyawarah Komite Sekolah, setelah disetujui pihak Sekolah, disampaikan kepada orang tua siswa baik melalui rapat maupun melalui surat. Semua keluhan yang disampaikan orang tua siswa, ditampung oleh Komite Sekolah yang selanjutnya akan disampaikan kepada pihak sekolah.

Sedangkan peran Komite Sekolah sebagai penghubung dalam hal pengelola sumber daya pendidikan dilakukan melalui pengindentifikasian kondisi sumber daya di sekolah dan masyarakat, sekaligus mobilisasi dan mengkoordinasikan bantuan masyarakat juga sudah berjalan. Oleh karena mayoritas pengurus Komite Sekolah adalah warga di lingkungan sekolah, maka mreka lebih memahami kondisi sumberdaya masyarakatnya dan dimudahkan dalam melakukan mobilisasi dan mengkoordinasikan bantuan masyarakat. Hal ini dibuktikan dengan adanya bantuan dari berbagai pihak kepada sekolah saat kegiatan persami se Kecamatan Jumo yang dilakukan di lingkungan SD Negeri Sukomarto. Komite sekolah memobilisasi dan mengkoordinasikan kebutuhan dan bantuan masyarakat, seperti kebutuhan lampu/penerangan, kebutuhan air dan keamanan.

Berdasarkan hal tersebut maka dapat disimpulkan bahwa Komite Sekolah SD Negeri Sukomarto dalam peran dan fungsinya sebagai badan penghubung di SD Negeri Sukomarto, sudah berjalan sebagaimana peran dan fungsinya, namun belum ada hubungan yang baik dengan Dewan Pendidikan.

\section{Pembahasan}

Hasil penelitian di atas menunjukkan bahwa kinerja Komite Sekolah SD Negeri Sukomarto sebagai badan pemberi pertimbangan dalam menjalankan fungsi perencanaan sekolah, pelaksanaan program, dan pengelolaan sumberdaya pendidikan termasuk kategori baik. Indikator kinerja Komite Sekolah sebagai badan per- timbangan (advisory agency) menurut Tim Pengembangan Komite Sekolah Ditjen Dikdasmen Depdiknas, antara lain adalah melaksanakan progam perencanaan sekolah, dengan mengidentifikasi sumber daya pendidikan dalam masyarakat, memberikan masukan terhadap penyusunan dan pengesahan RAPBS, menyelenggarakan rapat RAPBS, maupun memberikan pertimbangan tentang perubahan RAPBS telah diwujudkan oleh Komite Sekolah SD N Sukomarto.

Temuan ini menunjukkan bahwa proses pendidikan di SD N Sukomarto telah sesuai dengan amanat Undang-Undang RI Nomor 20 Tahun 2003 BAB IV pasal 1 yang menyebutkan bahwa masyarakat berhak berperan serta dalam perencanaan, pelaksanaan, pengawasan, dan evaluasi program pendidikan. Hasil penelitian ini sejalan dengan hasil penelitian yang dilakukan oleh Ninik (2011) dan Kriswanto (2013) yang menyatakan bahwa Komite Sekolah telah melaksanakan perannya sebagai badan pertimbangan. Tetapi hasil penelitian ini berbeda dengan hasil penelitian Armansyah (2009), yang menyimpulkan bahwa Komite Sekolah di lokasi penelitannya belum mampu melaksanakan peranannya sebagai badan pemberi pertimbangan.

Data hasil penelitian di atas juga menunjukkan bahwa kinerja Komite Sekolah SD N Sukomarto sebagai badan pendukung juga termasuk baik. Hal ini sesuai dengan amanat pemerintah yang tertuang dalam Indikator Kinerja Komite Sekolah yang diisusun oleh Tim Pengembangan Komite Sekolah Ditjen Dikdasmen khususnya tentang peran Komite Sekolah sebagai badan pendukung. Apa yang terjadi di lokasi penelitian membenarkan pendapat Haryanto, (2008:82) yang menyatakan bahwa: "Penekanan peran Komite Sekolah seharusnya bukan pada aspek dana saja tetapi juga aspek lainya, terutama berupa gagasan dalam rangka penyelenggaraan dan peningkatan mutu pendidikan". Juga pendapat dari Permadi, (2010:25) bahwa: "Dengan adanya hubungan kerjasama antara sekolah dengan masyarakat, dapat dicapai perpaduan antara sarana sekolah dengan masyarakat". Di samping hasil penelitian ini juga sejalan dengan hasil penelitian Kriswantoro (2013) yang menyebutkan bahwa Komite Sekolah di lokasi peneltiannya telah melaksanakan perannya sebagai badan pendukung.

Hasil penelitian di atas juga menunjukkan bahwa kinerja Komite Sekolah SD Negeri Sukomarto dalam menjalankan peran dan fungsinya 
sebagai badan pengontrol (controlling agency) termasuk cukup baik, karena hanya dilaksanakan bersamaan dengan dengan rapat dan melalui pencermatan terhadap laporan dari pihak sekolah. Hal itu terjadi karena masing-masing anggota Komite Sekolah mempunyai kegiatan sendiri sesuai profesinya, dan pihak sekolah tidak memiliki anggaran untuk biaya operasional Komite Sekolah. Hasil penelitian ini sejalan dengan penelitian yang dilakukan oleh Ninik (2011) yang menyimpulkan bahwa Komite Sekolah dilokasi penelitiannya telah dapat menjalankan fungsi controling dengan baik, sehingga dapat memperbaiki manajemen biaya pendidikan di sekolah tersebut. ApaIni sudah sesuai dengan amanat pemerintah yang tertuang dalam indikator kinerja

Hasil penelitian di atas juga menunjukkan bahwa kinerja Komite Sekolah SD Negeri Sukomarto dalam menjalankan peran dan fungsinya sebagai badan penghubung (mediator agency) termasuk cukup baik. Komite Sekolah sudah berusaha mewujudkan perannya sesuai dengan pendapat yang menyatakan "Tujuan Komite Sekolah adalah: (1) Mewadahi dan menyalurkan aspirasi dan prakarsa masyarakat dalam melahirkan kebijakan operasional dan program pendidikan di satuan pendidikan; (2) Meningkatkan tanggung jawab dan peran serta masyarakat dalam menyelenggarakan pendidikan di satuan pendidikan; (3) Menciptakan suasana dan kondisi transparan, akuntabel, dan demokratis dalam penyelenggaraan dan pelayanan pendidikan yang bermutu di satuan pendidikan (Haryanto, 2008:81)"

Dengan kinerja Komite Sekolah sebagaimana disajikan di atas maka SD N Sukomarto mengalami peningkatan yang signifikan. Di bidang mutu pendidikan pada tahun 2010/2011 hasil ujian mendapatkan peringkat 11 kecamatan, tahun 2011/2012 peringkat 10 kecamatan, tahun 2012/2013 10 kecamatan, tahun 2013/2014 peringkat 9 kecamatan. Padahal sebelun tahun pelajaran 2010/2011 hasil ujian SD Negeri Sukomarto tidak pernah masuk 10 besar di tingkat kecamatan. Sedangkan dibidang non akademik, dari tahun 2010/2011 sampai tahun 2014/2015 sering mendapat kejuaraan di tingkat kecamatan antara lain: juara 1 Khitobah, juara 1 Khot dan Kaligrafi, juara 2 rebana, juara 3 Tilawah. Di bidang sarana dan prasarana juga banyak terjadi peningkatan diantaranya adalah adanya sambungan listrik, WC siswa, tempat parkir, wastafel kelas, almari kelas, mushola, dan laptop serta printernya. Selain itu jumlah siswa yang semula hanya 60 siswa sedikit demi sedikit sudah mulai meningkat sehingga pada tahun 2014/2015 ini sudah mencapai 74 siswa.

Dengan perkataan lain kinerja Komite Sekolah SD Negeri Sukomarto sebagai badan pertimbangan (advisory agency) dan sebagai badan pendukung (supporting agency), sudah termasuk baik, sedang kinernya sebagai badan pengontrol (controlling agency) dan sebagai badan penghubbung (mediator agency), termasuk cukup baik. Peran untuk menjalin hubungan dengan Dewan Pendidikan belum terlaksana. Administrasi Komite Sekolah di SD Negeri Sukomarto juga belum baik, karena sewaktu peneliti mengadakan observasi dan studi dokumen tidak ditemukan Anggaran Dasar dan Anggaran Rumahtangga (AD/ART). Padahal menurut Satori, (2001: 71) salah satu tugas dan fungsi Komite Sekolah adalah menetapkan AD dan ART. Dalam Keputusan Mentri Pendidikan Nasional Nomor 044/U/2002 Tentang Dewan Pendidikan dan Komite Sekolah juga menyebutkan bahwa Komite Sekolah wajib memiliki AD dan ART. Di samping itu semua kegiatan Komite Sekolah selama ini juga tidak didokumentasikan dengan baik

\section{SIMPULAN}

Berdasarkan penelitian yang sudah dilaksanakan, kesimpulan yang dapat disajikan sebagai berikut.

(1) Kinerja Komite Sekolah sebagai badan Pemberi Pertimbangan (advisory agency) di SD Negeri Sukomarto Jumo Temanggung termasuk baik. Komite Sekolah SD Negeri Sukomarto sudah berperan aktif dalam memberi pertimbangan dan masukan terhadap perencanaan sekolah, pelaksanaan program dan pengelolaan sumberdaya. Dengan adanya masukan-masukan tentang program-program tersebut sedikit demi sedikit prestasi SD Negeri Sukomarto semakin meningkat baik dibidang akademik maupun non akademik.

(2)Kinerja Komite Sekolah sebagai badan Pendukung (supporting agency) di SD Negeri Sukomarto Jumo Temanggung, termasuk baik. Komite Sekolah sudah aktif memberikan dukungan terhadap pengelolaan sumberdaya, pengelolaan sarana dan prasarana serta pengelolaan anggaran pendidikan di SD Negeri Sukomarto. Banyak sarana dan prasarana yang telah diperbantukan kepada sekolah. Dengan 
tersedianya sarana dan prasarana yang memadai maka proses belajar mengajar dapat berjalan dengan lancar. Hal tersebut berpengaruh pada peningkatan mutu pendidikan baik akademis maupun non akademis.

(3) Kinerja Komite Sekolah sebagai badan Pengontrol (controlling agency) di SD Negeri Sukomarto Jumo Temanggung, termasuk cukup baik, walaupun dalam mengontrol kebijakan dan pelaksanaan program sekolah secara langsung belum optimal. Pemantauan dilakukan secara pasif yaitu melalui laporan yang diberikan pihak sekolah. Komite Sekolah juga memantau output pendidikan, sehingga semua siswa yang telah lulus bisa melanjutkan ke jenjang pendidikan lebih tinggi.

(4) Kinerja Komite Sekolah sebagai badan penghubung (Mediator Agency) di SD Negeri Sukomarto Jumo Temanggung, sudah termasuk cukup baik. Komite Sekolah menjalankan perannya sebagai badan penghubung dalam fungsi perencanaan, pelaksanaan program serta pengelolaan sumberdaya pendidikan. Tetapi untuk fungsi penghubung antara Komite Sekolah dengan Dewan Pendidikan belum bisa dilaksanakan, karena selama bertahun-tahun menjadi Komite Sekolah belum pernah berkoordinasi dengan Dewan Pendidikan.

\section{UCAPAN TERIMA KASIH}

Ucapan terima kasih disampaikan kepada Kepala Sekolah dan para guru di SDN Sukomerto Jumo Temanggung yang telah membantu proses penelitian ini. Terima kasih juga diucapkan kepada Reviewer dan Redaktur Jurnal Cakrawala Pendidikan yang telah memberi saran dan masukan perbaikan artikel ini. Harapannya, artikel ini bermanfaat bagi upaya pengembangan proses pembelajaran di sekolah.

\section{DAFTAR PUSTAKA}

Armansyah. 2009. Peranan dan Pemberdayaan Komite Sekolah dalam Penyelenggaraan Pendidikan SMA Negeri di Kota Binjai, online: http:// repository.usu.ac.id/ bitstream/ 123456789/7259/1/10E00531.pdf, diunduh Kamis, 4 Desember 2014, Jam 22.35.

Dirjen Dikdasmen Depdiknas, 2004. Panduan Umum Dewan Pendidikan dan Komite Sekolah.Jakarta
Fattah, Nanang, 2000. Ekonomi dan Pembiayaan Pendidikan. Bandung: PT Remaja Rosdakarya.

Haryanto. 2008. Komite Sekolah (Sejarah dan Prospeknya di Masa Depan). Yogyakarta: Hikayat Publishing.

Hasbullah, 2006. Otonomi Pendidikan (Kebijakan Otonomi Daerah dan Implikasinya Terhadap Penyelenggaraan Pendidikan. Jakarta: Rajawali Grafindo Persada.

Keputusan Mentri Pendidikan Nasional Nomor 044/U/2002 tentang Peran Dewan Pendidikan dan Komite Sekolah.

Kriswantoro, Mawan. 2013. Implementasi Peran Komite Sekolah di SD Negeri Sumberporong 03 Kecamatan Lawang, Kabupaten Malang: Hasil Penelitian, Universitas Negeri Yogyakarta.

Masaong dan Ansar. 2007. Manajemen Berbasis Sekolah. (Teori, Model, dan Implementasi di Sekolah Dasar). Gorontalo: Nurul Djanah.

Mulyasa. 2009. Manajemen Berbasis Sekolah. Bandung: PT Remaja Rusdakarya.

Mulyasa. 2009. Menjadi Kepala Sekolah Profesional, Bandung: PT Remaja Rusdakarya.

Ninik. 2011. Peranan Komite Sekolah Dalam Pembiayaan Pendidikan di SMA Negeri 1 Tuntang Kabupaten Semarang. http://journal. unnes.ac.id/nju/index. php/edukasi/ article/view/969/906, Diunduh Sabtu, 6 Desember 2014, jam 22.40.

Nurkolis. 2003. Manajemen Berbasis Sekolah. Jakarta: Grasindo.

Nyandoro, Joyce. 2013. Effectiveness Of School Development Committees In Financial Management In Chimanimani West Circuit Primary Schools In Zimbabwe,online: $\mathrm{http}: / /$ topkinsis.com/cnference/CCEAM/ wib/index/outline/PDF/CHIKOK, Diunduh Senin, 8 Desember 2014, Jam 08.23. 
Permadi D dan Arifin D, 2010. Kepemimpinan Transformasional Kepala Sekolah dan Komite Sekolah, Bandung: PT Sarana Panca Karya Nusa.

Satori, Dj. at al 2001.Pedoman Implementasi Manajemen Berbasis Sekolah di Jawa Barat: MBS Dewan Sekolah. Bandung: Dinas Pendidikan Jawa Barat untuk kalangan sendiri Simanjuntak, Payaman, 2005.
Manajemen dan Evaluasi Kinerja. Jakarta: Fakultas Ekonomi Universitas Indonesia.

Simanjuntak, P.J. 2005. Manajemen dan Evaluasi Kerja, Jakarta: Lembaga Penerbit FEUI

Undang-undang Republik Indonesia Nomor 20 Tahun 2003 tentang Sistem Pendidikan Nasional: Sinar Grafika. 